\title{
Changing thoughts towards digital literacy interventions for South African entrepreneurs
}

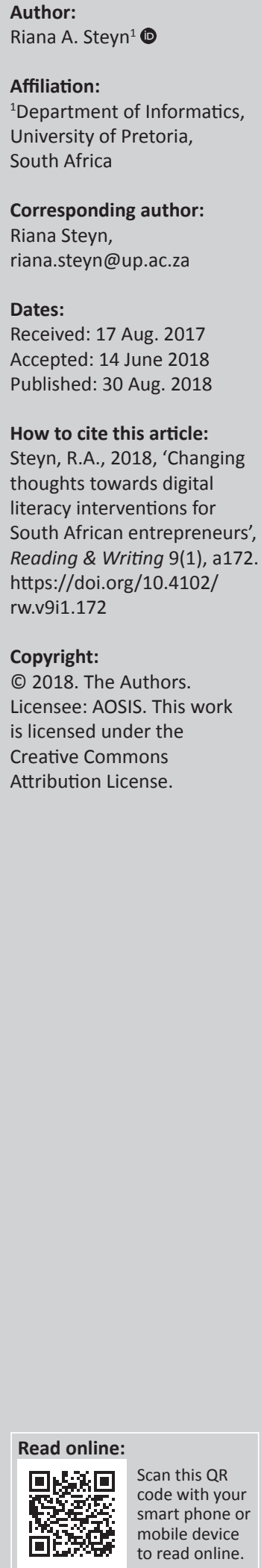

It has long been the focus of many countries around the world to see their entrepreneurs grow and to introduce interventions to assist them, as they realise the impact these entrepreneurs have on their economies. Technology is believed to be one of the biggest tools that entrepreneurs can use to assist them in growing sustainable businesses. There is an increased need for small businesses to employ information and communication technology (ICT) to enhance their businesses as part of their countries' socio-economic development. This, in turn, leads to an increased need for digital literacy interventions for these entrepreneurs. Many interventions have tried to assist a country's residents to adopt ICT and enhance their digital literacy levels. However, many of these did not have the desired outcomes. Many barriers prevent these initiatives from being successful, for example difficulty in retaining the current workforce, a lack of skills and human capital development, a lack of resources, security concerns, mistrust regarding ICT and ICT service providers and a lack of trust. Data were gathered over three years $(2012,2013$ and 2017) to determine whether there has been any change in the uptake of technology over time, whether technology is indeed the answer to many entrepreneurs' problems and whether some of the barriers could be overcome. An interpretivist paradigm using a qualitative approach was employed and 193 entrepreneurs were interviewed over three years to see if there was any change in their adoption of technology, which should be the case if one recognises the pace at which technology is changing. The identified barriers no longer seem to exist for South African entrepreneurs. It emerged that technology adoption and digital literacy studies should be industry-specific and should not be based on a generic approach. Thus, digital literacy cannot be used as a broad term and needs to be focused for each sector. This article proposes that most entrepreneurs have addressed one of the main barriers. These main barriers include a lack of expertise, in-house knowledge or a one-stop shop to assist with ICT queries and problems. Most of the entrepreneurs now have access to an information technology consultant or expert who can help them to become more digitally literate. Although many new technologies are being developed, certain standard software systems, such as the Microsoft Office package, will always be used. Thus, these standard software systems should be the focus of digital literacy training interventions. These interventions should be simple and easily accessible to everyone.

\section{Introduction}

It has long been a focus of many countries around the world to see their entrepreneurs grow. These countries have introduced interventions to assist entrepreneurs because they realise the impact these entrepreneurs have on their economies (Esselaar et al. 2006; Kunene 2008; Merkofer \& Murphy 2009; Oke, Burke \& Myers 2007; Talukder, Quazi \& Djatikusumo 2013; Thomas et al. 2004). This, in turn, leads to an increased need for digital literacy interventions for these entrepreneurs. Many countries focus on these interventions because small and medium enterprises (SMEs) are the driving force behind a country's economy and are regarded as essential for economic growth (Thomas et al. 2004). It is also seen as the answer to job creation and poverty reduction (Esselaar et al. 2006). Thomas et al. (2004) continue by stating that $99.8 \%$ of all firms in the European Union are SMEs. Peris et al. (2013) are of the opinion that these firms account for $65 \%$ of employment. Chatzoglou and Vraimaki (2010) substantiate this. They state that $95 \%$ of all companies in Greece are SMEs and account for $74 \%$ of the employment in the private sector. In South Africa, it is estimated that SMEs account for $90 \%$ of business establishments. Their contribution to the gross domestic product (GDP) is between $52 \%$ and $57 \%$, while their contribution to employment is $61 \%$ (Adeniran \& Johnston 2016; Cant, Wiid \& Hung 2016; Gono, Harindranath \& Berna Ozcan 2016; Mavimbela \& Dube, 2016). These numbers reflect a growth from 2005 when Antonites and Van Vuuren (2005) pointed out that small firms in South Africa contributed $47 \%$ to job creation. Cant et al. (2016) state that the sustainability and long-term success of these businesses become 
a crucial focus point. Thus, these small firms are seen as a tool to address world issues such as poverty and hunger.

Technology is believed to be one of the most important tools that these entrepreneurs can use to assist them in growing sustainable businesses (Adeniran \& Johnston 2016; Merkofer \& Murphy 2009; Steyn \& Leonard 2012; Thomas et al. 2004). There is an increased need for small businesses to employ information and communication technology (ICT) to enhance their businesses as part of their countries' socio-economic development. However, they also realise that there is a growing skills shortage (Mutula \& Van Brakel 2007; Uddin 2005). Cant et al. (2016) note that ICT is an essential success factor for many successful SMEs. Mutula and Van Brakel (2007) continue by stating that one of the major challenges faced by developing countries is the elevation of education and literacy, in general, and digital literacy, in particular. The markets are expanding globally for these SMEs because of innovations and new technologies.

Beck and Demirgüç-Kunt (2006), in Gono et al. (2016), note that one of the key reasons for poor ICT uptake could be resource constraints. In the same vein, it is said that one of the biggest needs and concerns of the adoption of ICT is that of the skills of SMEs; thus, their digital literacy skills are not what they should be (Gono et al. 2016:724). Gono et al. (2016) say that this skill 'is the new currency for SMEs'. Duncombe and Molla (2009:2) note from past experience that 'intervention for SMEs depends upon building enterprises' competence to process and use externally sourced information and knowledge resources'. Gono et al. (2016) note that one of the key issues still facing South Africa is the urgency to develop SMEs, as this would assist in the restructuring of the socio-economic change of the country. However, they also point out that SMEs do not feel that government is supporting them in these initiatives, as ' $81 \%$ of the survey respondents, 105 SMEs, report not having received any financial support from the government in relation to ICT investments' (Gono et al. 2016:727). These concerns need to be addressed to assist these small businesses to grow and become sustainable.

Numerous research studies have been conducted on SMEs, and numerous interventions have been launched, specifically in South Africa, to assist these entrepreneurs to grow sustainable businesses and become more digitally literate. A number of research studies have also focused on barriers and have attempted to explain why entrepreneurs will or will not adopt technology. However, little research has been performed over a longer period to see if there is a change in ICT uptake by SMEs, and entrepreneurs specifically. There is also limited research on what the focus should be for digital literacy interventions. Many interventions have been initiated to train these SMEs. However, many attempts have been made where these initiatives did not have the desired outcomes (Twinomurinzi, Phahlamohlaka \& Byrne 2012).

The dynamic capabilities theory (Teece 2007; Teece, Pisano \& Shuen 1997) is used to look at the changing entrepreneurs in South Africa. Adeniran and Johnston (2016) note that entrepreneurs cannot only have ICT or dynamic capabilities. They must rather have a combination of the two to become successful entrepreneurs. Thus, how the entrepreneurs sensed, seized and managed threats or transformation are seen as dynamic capabilities (Teece 2007). Data gathered were investigated over three years (2012, 2013 and 2017) to see if there was any change in the uptake of technology over time. The barriers identified by various authors may no longer be considered when planning entrepreneurial ICT interventions.

This article contributes to the field of digital literacy because it indicates a change in the number of barriers that exist. For example, a barrier such as a lack of expertise, in-house knowledge or lack of a one-stop shop to assist with ICT queries and problems no longer exists. Most entrepreneurs now have access to an information technology (IT) consultant or expert who can assist them in increasing their digital literacy knowledge. Another more practical contribution of this article is that it provides new knowledge on industryspecific interventions (such as those used by smaller retailers, smaller restaurants and dentists). Thus, digital literacy should not be used as a broad term, but the focus should rather be on industry-specific needs.

\section{Entrepreneurs}

Entrepreneurs are classified differently in various countries. According to Section 4 of the National Small Business Act of 1996 (Republic of South Africa 1996), a small business is defined as a small organisation, corporate and nongovernmental structure that is mostly managed by the owner. Small businesses are categorised according to their sector and size, as well as their income and asset value. They are further categorised as micro, very small, small or medium enterprises. This article focuses on microenterprises ${ }^{1}$ or entrepreneurs that are categorised as having no more than five employees (Cant et al. 2016; Gono et al. 2016; Republic of South Africa 1996). The National Small Business Act also classifies entrepreneurs based on a total annual turnover of ZAR150 000 per annum and a total asset value of ZAR100 000. For this study; however, turnover and total asset value were never determined. Thus, only entrepreneurs or micro-enterprises with five employees and less were considered.

\section{Theoretical background}

The dynamic capabilities theory served as a theoretical lens, and principles are briefly discussed. Cant et al. (2016) note that more hands-on interventions are required from government to ensure that the infrastructure in the rural areas can facilitate ICT uptake by entrepreneurs and assist in increasing general digital literacy level. This article will talk about ICT uptake or adoption, as this indicates whether or not there is an increase in digital literacy levels.

1.For the sake of simplicity, this article will use the term 'entrepreneurs' throughout. 
According to Alam and Noor (2009), the following five variables affect the adoption of ICT:

- perceived benefits

- perceived costs of adoption

- information and communication technology knowledge and skills of employees (digital literacy)

- external pressure

- government support.

Individual, organisational, environmental, technological and economic factors are also linked to technology adoption (Cant et al. 2016). Many authors have also looked at the adoption of technology through various technology adoption models that have been developed in an attempt to understand ICT adoption, in general, and SMEs, in particular (Al Mursalin 2012; Anderson \& Schwager 2004; Bagozzi 2007; Baker \& White 2010; Bhattacherjee \& Sanford 2006; Burnkrant \& Page 1988; Cáceres et al. 2012; Chatzoglou \& Vraimaki 2010; Cohen, Bancilhon \& Jones 2013; Escobar-Rodríguez \& Carvajal-Trujillo 2014; Fadel, Durcikova \& Cha 2008; Godin \& Goette 2013; Hameed, Counsell \& Swift 2012; Handy, Whiddett \& Hunter 2001; Hansen, Jensen \& Solgaard 2004; Im, Hong \& Kang 2011; Jackson \& Sloane 2009; Kumar 2013; Lu et al. 2003; Malebana 2014; Marchewka, Liu \& Kostiwa 2007; Mehrtens, Cragg \& Mills 2001; Nguyen 2009; Oye, Ihhad \& Ab Rahim 2012; Peris et al. 2013; Ramalho, Moura \& Cunha 2015; Ramdani \& Kawalek 2009; Reimenschneider, Harrison \& Mykytyn 2003; Spencer, Buhalis \& Moital 2012; Suri 2011; Talukder et al. 2013; Uddin 2005; Venkatesh et al. 2003; Wamuyu \& Maharaj 2011; Wonglimpiyarat \& Yuberk 2005; Yu 2012). Venkatesh et al. (2003) state that one of the most mature research discussions in information systems is that of explaining how users accept certain technologies. One of the adoption theories that currently exist is the dynamic capabilities theory.

The dynamic capabilities theory (Teece et al. 1997:516), which can be defined as 'the firm's ability to integrate, build and reconfigure internal and external competences to address rapidly changing environments', was used in this article. Teece et al. (1997) continue to state that the dynamic capabilities approach focuses specifically on the rapidly changing technology market and how firms can adapt to these markets to ensure a competitive advantage. In their viewpoint, 'dynamic' refers to a firm's capabilities to quickly adapt to fast-changing environments, and being innovative and able to ensure timely market penetration (Teece et al. 1997). Dynamic capabilities are the firms' abilities to change their resources by designing certain processes in the organisation (Adeniran \& Johnston 2016). Adeniran and Johnston (2016) continue by saying that these capabilities enable quick responses to changing environments and opportunities. When viewing entrepreneurs, they are willing to take risks and be innovative when penetrating the market. Entrepreneurs can adapt to change more rapidly than larger organisations (Adeniran \& Johnston 2016; Oke et al. 2007). Thus, they are more dynamic. Because of this ever-changing and rapid adoption that entrepreneurs should be able to adapt to, it is not surprising that most entrepreneurial training interventions focus on risk management (Botha, Nieman \& Van Vuuren 2007; Hisrich \& Peters 1998; Hynes 1996; Kourilsky 1995; Noll 1993; Onstenk 2003).

Capabilities refer to the adaptability of the organisations, in this case, the entrepreneurs (Teece et al. 1997), to rapidly adapt to changes in the environment and opportunities (Adeniran \& Johnston 2016). Entrepreneurs are adaptable and re-organise certain skills, resources and even their functional resources in this ever-changing environment. According to Adeniran and Johnston (2016), there are six major attributes of dynamic capabilities, and each attribute follows on the preceding attribute's outputs:

- Sensing capability: entrepreneurs should be aware of market changes and should be able to accurately predict how customers will react.

- Absorptive capability: after the sensing capability is acquired, an organisation acquires the absorptive capability. Once new internal and external knowledge is gained from sensing, this is transformed into useful information to be used during decision-making.

- Adaptive capability: this is the capability to quickly reconfigure resources to respond to the knowledge gained.

- Innovative capability: this refers to the ability to do things in new ways based on the knowledge gained. This allows an entrepreneur to continuously redevelop and perhaps redesign certain resources or assets.

- Networking capability: this refers to how the organisation establishes relationships to acquire various resources.

- Integrative capability: this is the capability to use all the resources and competencies gained from the previous five attributes in order to function together to gain a competitive advantage.

Entrepreneurial firms that enter new markets cannot necessarily replicate specific organisational skills. One has to understand the business and the underlying structures that support the business operations. Sensing, seizing and managing threats or transformation are seen as dynamic capabilities (Teece 2007). Coordination or integration, learning and reconfiguring are subsets of the processes of sensing, seizing and managing threats or transformation.

Teece et al. (1997) continue by saying that minor technological changes can have devastating effects on a firm's competiveness in a market. Thus, it is necessary to determine if there is a change in the mindsets of these entrepreneurs and their adoption of technology over the last few years. The concepts of sensing, seizing and transformation (Teece 2007) will be used, first of all, to see if the entrepreneurs have sensed and seized the need to increase their digital literacy and adoption of technology over the years. They will also be used to determine if the barriers identified in the literature are still relevant to today's entrepreneurs. The reason for looking at the entrepreneurs' ICT adoption, as well as their digital literacy, through the dynamic capabilities lens, was because 
of the fact that dynamic capabilities were found to have a positive effect on ICT utilisation and adoption (Adeniran \& Johnston 2016).

There are various reasons why people will still not accept technology, even when one has followed the approach of a technology adoption model when introducing it, and one has ensured that, according to the theory, it is $100 \%$ correct. Thompson et al. (2010) acknowledge that, even though ICT can be seen as a huge benefit to SMEs, it also brings about a threat for these SMEs and entrepreneurs, as they have mostly limited resources available to use and benefit from these technologies. One of these threats is a lack of skills. This ties in with Teece (2007), who sees transformation in the same way as managing threats. This threat can be regarded as a barrier that entrepreneurs will have to overcome to introduce ICT or even ensure a sustainable business that incorporates ICT.

Various studies focus on the reason why certain technologies are accepted or rejected. Although Cant et al. (2016) said that each country's barriers are unique, which they are, Table 1 shows various authors' views on why technology is not being adopted by SMEs across the world.

The list of barriers is almost endless, and it is important to realise that one cannot take any adoption model and decide that it will be the reason for adoption. One has to consider various aspects. Many of these barriers are also linked or might stem from the entrepreneur's digital illiteracy. Although the list of barriers is rather long, this article sets out to determine if these barriers still exist. However, it does not focus on all the barriers, and the author only examined certain barriers. This article focuses on the preferred communication methods used for clients, the importance of mobile technologies for entrepreneurs, how they managed to continuously adapt in this ever-changing competitive environment to remain competitive and/or become digitally literate, and lastly, who the decision-makers are. This article does not consider barriers such as a lack of resources, high cost, legal aspects, cultural barriers and performance risk.

\section{Decision-makers}

For a long time, it was said that the decision-makers in these small businesses are the owners themselves ( $\mathrm{Yu}$ 2001). However, recent studies have proven that other factors, such as suppliers and IT consultants, can play a role in the adoption of ICT (Gono et al. 2016). Mavimbela and Dube (2016) find that the low skills levels (low digital literacy capabilities) of owners could result in a low adoption rate. This is also listed as a barrier above, which is why it will be interesting to see who makes the decisions.

\section{Methodology}

The interpretivist philosophy was selected because this study conducted interviews. This allowed the researcher to transcribe, compare and interpret the data. Five interview questions were used to assist in profiling the entrepreneurs
TABLE 1: Barriers to adoption

\begin{tabular}{|c|c|}
\hline Reason to adopt or not & Source \\
\hline Lack of resources & $\begin{array}{l}\text { - Mutula and Van Brakel (2007) } \\
\text { - Kahn et al. (2012) } \\
\text { - Miller and Garnsey (2000 } \\
\text { - Reimens et al. (2004) } \\
\text { - Nguyen (2009) } \\
\text { - } \text { Chatzoglou and Vraimaki (2010) } \\
\text { - } \text { Kabanda (2011) } \\
\text { - } \text { Mavimbet al. (2016) } \\
\text { Mavimbela and Dube (2016) }\end{array}$ \\
\hline $\begin{array}{l}\text { Difficult to retain current workforce, } \\
\text { lack of skills and human capital } \\
\text { development, limited ICT capabilities }\end{array}$ & $\begin{array}{l}\text { - Mutula and Van Brakel (2007) } \\
\text { - Kapurubandara and Lawson (2007) } \\
\text { - Kahn et al. (2012) } \\
\text { - Miller and Garnsey (2000) } \\
\text { - Eguyen (2009); } \\
\text { - Esselaar et al. (2006) } \\
\text { - Godzani and Van Vuuren (2002) } \\
\text { - Cano et al. (2016) } \\
\text { - Mavimbela and Dube (2016) } \\
\text { - Adeniran and Johnston (2016) }\end{array}$ \\
\hline $\begin{array}{l}\text { Effective leadership, ownership and } \\
\text { management }\end{array}$ & $\begin{array}{l}\text { - Spencer et al. (2012) } \\
\text { - Uddin (2005) } \\
\text { - Kahn et al. (2012) } \\
\text { - Miller and Garnsey (2000) }\end{array}$ \\
\hline Access to information and strategy & - Kahn et al. (2012) \\
\hline Political and social barriers & - Kapurubandara and Lawson (2007) \\
\hline $\begin{array}{l}\text { Security concerns, mistrust regarding } \\
\text { ICT and ICT service providers }\end{array}$ & $\begin{array}{l}\text { - Gatautis and Vitkauskaite (2009) } \\
\text { - Kapurubandara and Lawson (2007) } \\
\text { - AlAwadhi and Morris (2008) } \\
\text { - Wamuyu and Maharaj (2011) } \\
\text { - Cohen et al. (2013) }\end{array}$ \\
\hline $\begin{array}{l}\text { Lack of infrastructure and technical } \\
\text { challenges (risk of the product } \\
\text { malfunctioning) }\end{array}$ & $\begin{array}{l}\text { - Kahn et al. (2012) } \\
\text { - Kapurubandara and Lawson (2007) } \\
\text { - Ramani, SadreGhazi and Duysters (2012) } \\
\text { - Suri (2011) } \\
\text { - Esuyen (2009) } \\
\text { - } \text { Wamuar et al. (2006) } \\
\text { - Mavimbela and Dube (2016) }\end{array}$ \\
\hline Legal framework and legal aspect & $\begin{array}{l}\text { - Kahn et al. (2012); Kapurubandara and } \\
\text { Lawson (2007) } \\
\text { - AlAwadhi and Morris (2008) }\end{array}$ \\
\hline Cultural barriers or constraints & $\begin{array}{l}\text { - Kapurubandara and Lawson (2007); } \\
\text { Kahn et al. (2012) }\end{array}$ \\
\hline $\begin{array}{l}\text { Lack of a one-stop facility and access } \\
\text { to reliable experts, and difficulty of } \\
\text { keeping systems serviced and } \\
\text { upgraded }\end{array}$ & $\begin{array}{l}\text { - Kapurubandara and Lawson (2007) } \\
\text { - Thomas et al. (2004) } \\
\text { - Ldubisi and Kahraman (2005) } \\
\text { - Ladzani and van Vuuren (2002) }\end{array}$ \\
\hline Financial constraints and high costs & $\begin{array}{l}\text { - Kahn et al. (2012) } \\
\text { - Ramani et al. (2012) } \\
\text { - Thomas et al. (2004) } \\
\text { - Nguyen (2009) } \\
\text { - Esselaar et al. (2006) } \\
\text { - Donner and Escobari (2010) } \\
\text { - Ndubisi and Kahraman (2005) } \\
\text { - Ladzani and Van Vuuren (2002) } \\
\text { - Wamuyu and Maharaj (2011) } \\
\text { - Cant et al. (2016) } \\
\text { - Adeniran and Johnston (2016) }\end{array}$ \\
\hline $\begin{array}{l}\text { Lack of knowledge, unfamiliar, thus } \\
\text { leading to perception that ICT is too } \\
\text { complicated, and lack of confidence }\end{array}$ & $\begin{array}{l}\text { - Ramani et al. (2012) } \\
\text { - Esselaar et al. (2006) } \\
\text { - Ndubisi and Kahraman (2005) } \\
\text { - KlAwadhi and Morris (2008) } \\
\text { - Kabanda (2011) } \\
\text { - Mavimbela and Dube (2016) }\end{array}$ \\
\hline $\begin{array}{l}\text { Access to mobilisation of } \\
\text { organisational resources (such as } \\
\text { reputation and brand equity) }\end{array}$ & - Miller and Garnsey (2000) \\
\hline No need for ICT & $\begin{array}{l}\text { - Esselaar et al. (2006) } \\
\text { - Cant et al. (2016) }\end{array}$ \\
\hline Limited availability & $\begin{array}{l}\text { - Donner and Escobari (2010) } \\
\text { - Oye et al. (2012) } \\
\text { - Adeniran and Johnston (2016) }\end{array}$ \\
\hline $\begin{array}{l}\text { Performance risk (increase in } \\
\text { productivity because of ICT, } \\
\text { increase in job performance } \\
\text { and useful for my work) }\end{array}$ & $\begin{array}{l}\text { - Wamuyu and Maharaj (2011); } \\
\text { Cant et al. (2016) }\end{array}$ \\
\hline
\end{tabular}
and usefultor my work)

ICT, information and communication technology.

Note: Please see the full reference list of the article, Steyn, R.A., 2018, 'Changing thoughts towards digital literacy interventions for South African entrepreneurs', Reading \& Writing 9(1), a172. https://doi.org/10.4102/rw.v9i1.172, for more information.

to determine their current ICT adoption status. During this stage, students helped the researcher to interview approximately 684 companies. 
The interviews formed part of an undergraduate course for students who had to understand the importance of information systems in today's economy. The students were given a set of interview questions that were set up to allow semi-structured interviews to be conducted. These students were given instructions on how to conduct an interview and how to approach a business, as it was the first time they had performed this type of assignment. This is also why they received a set of specific questions that allowed for formal, structured interviews. The students could approach any business of their choice and had to conduct an interview with this business. Before these students could conduct the interviews, they were informed of the process to follow to allow for maximum information retrieval. A total of 481 final interviews were conducted and transcribed over a 2-year period from 2012 to 2013. In 2017, 203 interviews were conducted. All the data were initially captured on a Microsoft Excel spreadsheet, after which the data were analysed. All the data were added up to compare the various responses. The data were analysed according to specific themes by interpreting all the responses from the various participants across the different years.

In order for this study to be specifically focused on entrepreneurs, only 155 of the interviews were used. Some 84 of the interviews conducted with entrepreneurs in 2012, and 71 of the interviews conducted with entrepreneurs in 2013 were used. In addition, 38 of the interviews conducted in 2017 were used. The students could select participants anywhere in South Africa. The researcher had no control over who was interviewed. This ensured that a random sample of entrepreneurs was interviewed. Each business that was interviewed had to provide a business card or stamp to prove that it was a legitimate business. This ensured that a wide variety of industries was covered.

Although the researcher used the number of employees as a benchmark to determine whether it was indeed an entrepreneur that was being interviewed, some franchises were also interviewed. Because franchises obtain their technology and systems from the franchisor, these entrepreneurs were excluded from the analysis. Thus, none of the entrepreneurs interviewed were part of a franchise.

\section{Findings}

Table 2 shows the number of employees in each of the interviewed businesses. The number of employees determined whether the entrepreneurs could be included based on the definition of an entrepreneur.

The interviewees were asked which province their primary business operated from. It is important to note that this question was never part of the 2012 interview questions; thus, only the provinces of the interviewees from 2013 and 2017 could be listed. The majority of the entrepreneurs were from Gauteng. However, there were a few from other provinces, which would not be excluded from this study because of the richness of the data, see Table 3 .
TABLE 2: Number of employees.

\begin{tabular}{lccc}
\hline No. of employees & $\mathbf{2 0 1 2}$ & $\mathbf{2 0 1 3}$ & $\mathbf{2 0 1 7}$ \\
\hline 1 & 11 & 6 & 5 \\
2 & 15 & 13 & 8 \\
3 & 23 & 11 & 6 \\
4 & 17 & 21 & 8 \\
5 & 19 & 22 & 11 \\
\hline
\end{tabular}

TABLE 3: Province of primary business.

\begin{tabular}{lcc}
\hline Province & $\mathbf{2 0 1 3}$ & $\mathbf{2 0 1 7}$ \\
\hline Eastern Cape & 0 & 0 \\
Free State & 1 & 0 \\
Gauteng & 64 & 35 \\
KwaZulu-Natal & 2 & 0 \\
Limpopo & 0 & 0 \\
Mpumalanga & 0 & 0 \\
North West & 2 & 2 \\
Northern Cape & 0 & 0 \\
Western Cape & 2 & 0 \\
International & 0 & 1 \\
\hline
\end{tabular}

All the findings were compared across the 3 years and calculated as the percentage of that year's participants to ensure that a proper comparison could be performed.

The interviewees were asked how they primarily communicate with their clients. The results illustrated in Table 4 are interesting, as there does not seem to be any change in the uptake of technology to communicate with their customers. Face-to-face appointments declined by almost 10\% in 2017. There was a slight increase in the use of Twitter (12\%) and Facebook (15\%), with a decline in cell phone use in 2017. Overall, Mavimbela and Dube (2016) found social media to be a useful tool for attracting more customers. However, it seems that the entrepreneurs in this study were still lagging behind on fully realising what social media can do for their businesses or they do not understand the platforms. The biggest change was the use of fax lines; which almost no one uses anymore. Only $18 \%$ of the interviewees reported using this technology in 2017, compared to 51\% who were using this technology in 2013. Interestingly, Cant et al. (2016) noted in 2016 that $92 \%$ of the SMEs in their study said that they used email, and $61 \%$ said that they used a company website. Although their study was based on SMEs, the results for the entrepreneurs specifically were lower, which proves that one has to be careful not to generalise the findings from SMEs and apply them to all entrepreneurs. However, this correlates with Steyn and Leonard (2012), who said that micro-businesses will only use email, and only when businesses are classified as 'small' will they start using a company website. Thus, it is recommended that any intervention that increases the entrepreneurs' literacy levels and assists with ICT should focus on effective email use, as this is clearly the biggest uptake for entrepreneurs.

The interviewees were asked how they stay abreast of the ever-changing and competitive IT environment. In 2012, the most common themes that emerged were internet updates and software upgrades. Most of them also said that they keep an eye on the internet. 
TABLE 4: Preferred communication with clients.

\begin{tabular}{|c|c|c|c|c|c|c|c|c|c|c|c|c|}
\hline Year & $\begin{array}{c}\text { Walk-in } \\
(\%)\end{array}$ & $\begin{array}{c}\text { Appointment } \\
\text { face-to-face (\%) }\end{array}$ & $\begin{array}{c}\text { Twitter } \\
(\%)\end{array}$ & $\begin{array}{c}\text { Facebook } \\
(\%)\end{array}$ & $\begin{array}{c}\text { Cell } \\
\text { phone (\%) }\end{array}$ & $\begin{array}{c}\text { Website } \\
(\%)\end{array}$ & $\begin{array}{c}\text { Landline } \\
(\%)\end{array}$ & $\begin{array}{l}\text { Blogs } \\
(\%)\end{array}$ & $\begin{array}{l}\text { Linkedln } \\
(\%)\end{array}$ & $\begin{array}{c}\text { Call } \\
\text { centre (\%) }\end{array}$ & $\begin{array}{c}\text { Fax line } \\
(\%)\end{array}$ & $\begin{array}{c}\text { Email } \\
(\%)\end{array}$ \\
\hline 2012 & 85 & 75 & 10 & 27 & 89 & 46 & 67 & 6 & 13 & 7 & 55 & 85 \\
\hline 2013 & 84 & 74 & 6 & 30 & 74 & 51 & 65 & 4 & 20 & 9 & 51 & 78 \\
\hline 2017 & 84 & 63 & 18 & 45 & 68 & 47 & 68 & 11 & 18 & 8 & 18 & 76 \\
\hline
\end{tabular}

One participant said:

'... own internet searches, looking at the IT Web, Wired and CIO websites, which are rich in information.' (Producer, 2012 group)

Another comment from a 2012 participant was:

'I try to keep up with the latest advancements of the IT world, since it is a faster, cheaper and easier way to advertise and communicate with possible clients. The IT environment is part of my business, thus it is very important for me to keep up with such an ever-changing world.' (Electrician, 2012 group)

There were; however, four participants who said that they do nothing to keep up, they just perform their daily operations:

'Currently, I do not keep up with trends in the IT environment.' (Dentist, 2012 group)

One participant said that their children help them with their technology. Some of the participants mentioned that they have an IT consultancy firm that they can contact from time to time. All in all, in 2012 it seemed as if entrepreneurs already realised the importance of keeping up to date with technology and the ever-changing environment.

In 2017, this trend looked almost the same. Internet updates and software upgrades were the common themes (identified by 12 interviewees). What was interesting though, was that 10 respondents $(26 \%)$ reported using IT consultants or having IT departments. This seems strange, as typically entrepreneurs will not have an IT department or make use of a consultant because of the cost involved (Steyn \& Leonard 2012). However, there does seem to be an increase in the need for an IT consultant or IT department.

The interviewees had similar responses when they were asked who the decision-makers were in their businesses, see Table 5 .

A company only sees the need to employ an in-house IT resource once they have developed into a medium-sized business (Steyn \& Leonard 2012). However, these results show that although they might not directly appoint an IT consultant, as most of them are on a retainer or part-time contract, entrepreneurs are starting to see the need to consult someone with IT knowledge to assist them. This could also be attributed to the fact that they do not have the skills. This corresponds to the findings of Cant et al. (2016) that a lack of ICT knowledge and understanding, as well as the lack of skilled workers who can maintain systems, is seen as a barrier towards technology adoption for the South African entrepreneur. This indicates a shift in their mindset. The sensing that the IT expert might help them and seizing this help correlates with the dynamic capabilities theory.
TABLE 5: Decision-makers.

\begin{tabular}{lccc}
\hline Decision-makers & $\mathbf{2 0 1 2}(\mathbf{\%})$ & $\mathbf{2 0 1 3}(\mathbf{\%})$ & $\mathbf{2 0 1 7}(\mathbf{\%})$ \\
\hline Clients & 5 & 7 & 0 \\
Eskom & 1 & 0 & 0 \\
Head office or manager & 2 & 21 & 14 \\
Department or vendor IT or consultant & 49 & 45 & 41 \\
No one & 4 & 4 & 0 \\
Owner & 29 & 8 & 16 \\
Partner & 0 & 0 & 8 \\
Family and/or friends & 4 & 10 & 5 \\
Colleagues & 4 & 3 & 5 \\
Blank & 4 & 1 & 11 \\
\hline
\end{tabular}

$\mathrm{IT}$, information technology.

The typical systems implemented remained similar across all 3 data sets. These are the standard Microsoft Office packages and Pastel Accounting. Other typical systems are industryspecific systems, such as point-of-sale systems for coffee shops, Galileo for travel agencies, computer-aided design (CAD) drawing systems for architects and construction companies, Medimass for medical practices and Corel Draw for design companies. These systems were mentioned in all three data sets. It is interesting to note that two different tattoo companies said that they did not use any systems at all in 2012 and 2013. These companies were not interviewed in 2017. However, a gym that did not use any system at all was interviewed in 2017.

When asked whether they think they could run their business without having any IT in place (a question only asked of the 2017 group), 26 interviewees (68\%) said that they could not, three said that they were not sure and eight said that they could. One of the barriers listed above, as mentioned by Esselaar et al. (2006) and Cant et al. (2016), was that entrepreneurs do not see the need for ICT in their businesses. Some $21 \%$ of the 2017 group still feels this way.

When interviewees were asked whether they think there is a place for mobile devices in their business in the future, an interesting trend emerged. Although the results illustrated in Table 6 clearly show that most entrepreneurs realised the importance of or the place of mobile devices in their future, the industries did not think that there is a place for mobile devices in their businesses. These results were almost the same across all three years. In 2012 these companies included two retail businesses, one dentist, one small sushi restaurant, one attorney practice and one internet café. In 2013 three retailers, one dentist, one internet café and one dance studio thought that there was no place for mobile devices in their businesses. In 2017 a dental practice and a beauty salon did not think that there was a place for mobile devices in their business in the future. None of the 
TABLE 6: Future mobile use.

\begin{tabular}{lccc}
\hline Yes or No or Unsure & $\mathbf{2 0 1 2}(\mathbf{\%})$ & $\mathbf{2 0 1 3}(\mathbf{\%})$ & $\mathbf{2 0 1 7}(\mathbf{\%})$ \\
\hline Yes & 91 & 90 & 92 \\
No & 7 & 9 & 5 \\
No answer or not sure & 2 & 1 & 3 \\
\hline
\end{tabular}

companies providing similar responses across the three years were the exact same businesses. This proves the viewpoint of Teece et al. (1997) that one cannot replicate certain organisational structures for all businesses. One has to understand the specific markets. For certain businesses, best practice may be illusive. Thus, the business might not understand the relevance of the technology in question.

It seems as if certain industry sectors feel that mobile technology has a limited influence on their future business. Some of the following quotes were received from the interviewees:

'Mobile devices are very limited in this line of business, as it is an office-run business and all operations are performed in the office. Laptops could help mobility, but it is not needed by any of the employees.'(Attorney, 2012 group)

'No, mobile devices such as cell phones or laptops would not have any positive influence on my business. But mobile systems for ordering and paying customers would be very helpful in terms of time and efficiency in the future. Mobile stock control.' (Restaurant Manager, 2012 group)

'No, we don't deal with mobile devices and our store has personal computers and landlines, making mobile devices unnecessary.' (Retailer Owner, 2012 group)

'Currently we do not see any possibility for mobile technology, but given the ever-changing world of IT and customer demand, we can never be sure what will happen in the future.' (Internet Cafe Owner, 2012 group)

The following participants agreed that there is a place for mobile devices in their business in the future and mentioned that they can monitor their business off-site:

'Patients will be able to set up appointments without speaking to the administration.' (Medical doctor, 2017 group)

'With the current move to the cloud, it is easier to service the client anywhere, anytime.' (Accountant, 2017 group)

It is evident that the specific industry sector in which these businesses fall will determine their need for mobile technology. Although the literature mentioned that mobile devices should be seen as a powerful tool in entrepreneurs' daily operations (Cáceres et al. 2012; Esselaar et al. 2006; Kabanda 2011; Twinomurinzi et al. 2012:210; Wamuyu \& Maharaj 2011), it seems as if this could be industry-specific. Interventions should target specific industry sectors and one should be careful to make statements such as those made by Mavimbela and Dube (2016) when they say that a framework that works in one province can be implemented and will be able to serve a larger SME focus. However, they also agree that certain industries, specifically labour-intensive industries, have not explored the benefits of ICT for their businesses, which correlates with the findings of Mavimbela and Dube (2016).

\section{Discussion}

It seems that even the researcher's own focus should shift, even though she is an avid entrepreneurial researcher. Many countries noted the need to invest in SMEs because they form a large part of the country's economy (Esselaar et al. 2006; Kunene 2008; Merkofer \& Murphy 2009:1198; Oke et al. 2007; Talukder et al. 2013; Thomas et al. 2004). However, we all make mistakes when it comes to entrepreneurial interventions and entrepreneurs' digital literacy skills, and we all assume that certain barriers still exist. This article makes a practical contribution because it identifies various needs for specific interventions.

There seems to be a need to focus on industry-specific interventions (such as those for smaller retailers, restaurants and dentists) to assist these entrepreneurs with their ICT uptake and increase their digital literacy. Thus, specific interventions should target these specific industries to ensure that they are made aware of available technology. This could also tie in with the barrier of limited availability of ICT (Donner \& Escobari 2010; Oye et al. 2012) for these industries or perhaps a lack of knowledge. Unfamiliarity, thus leading to the perception that ICT is too complicated, and a lack in confidence (AlAwadhi \& Morris 2008; Esselaar et al. 2006; Kabanda 2011; Mavimbela \& Dube 2016; Ndubisi \& Kahraman 2005; Ramani, SadreGhazi \& Duysters 2012) could also be seen as reasons why these industries did not adopt ICT. They should be made aware of specific technologies that are available in their industries.

Two of the barriers highlighted above were the lack of a one-stop facility and access to reliable experts, as well as the difficulty of keeping systems serviced and upgraded (Kapurubandara \& Lawson 2007; Ladzani \& Van Vuuren 2002; Ndubisi \& Kahraman 2005; Thomas et al. 2004). However, from the findings above, it seems that this is no longer the case. Most entrepreneurs said that they keep up to date by performing system updates. The majority of them said that they have access to an IT consultant, and thus there seems to be a shift in the mindset of these entrepreneurs. This ties in with the networking capability as mentioned earlier (Adeniran \& Johnston 2016), whereby organisations use their networks to establish relationships and thus have access to external resources if and when needed. Linked to this, the barriers of security concerns, mistrust regarding ICT and ICT service providers, and lack of trust (AlAwadhi \& Morris 2008; Cohen et al. 2013; Gatautis \& Vitkauskaite 2009; Kapurubandara \& Lawson 2007; Wamuyu \& Maharaj 2011) also seem to be falling away.

It seems that entrepreneurs have sensed the need to contract someone who can assist them on certain aspects when one looks at the dynamic capabilities and the focus on sensing, seizing and managing threats or transformation. 
Thompson et al. (2010) acknowledged that SMEs mostly have limited resources available for use. However, it seems that the entrepreneurs are making a mindshift. They are realising the need to update and upgrade their systems. The need to have access to someone who has knowledge of ICT also emerged. This, however, seems to be true for certain industries, but not for others.

This article makes a main practical contribution with regard to the real need of the entrepreneurs. If interventions are to be designed to assist these entrepreneurs to successfully embrace ICT, digital literacy should be the main focus.

\section{Future research}

This article focused on entrepreneurs over a period of three years. However, in this ever-changing ICT environment, the study will never be complete. Each year similar studies will be conducted to ensure that the recommendations made for future entrepreneurial interventions are relevant for the current entrepreneurs in the most recent ICT environment. Thus, the ever-changing ICT environment is seen as a limitation of this study, as one will never be quite complete with this study or with similar studies.

\section{Conclusion}

Information and communication technology is seen as an extension to the term 'information technology', which is technology on an integrated telecommunications platform used by many to access information and use this information in various ways (Cant et al. 2016). Many researchers have noted that ICT is crucial for many SMEs to survive. It emerged from this study that, even though there are many benefits of ICT adoption and interventions on the market to improve the success of entrepreneurs, there does not seem to be such a great shift in technology uptake over a 44-year period. More so, the specific industry type seems to be a determining factor of technology uptake. This correlates with the findings of Mavimbela and Dube (2016) when they say that SMEs prefer to stick to general technology because of the cost and perceived complicated nature of ICT. This, however, is in contrast to their own defining statement where SMEs are seen as risk takers and innovators. That being said, it emerged that some of the barriers various authors identified are not barriers for the South African entrepreneur. Thus, one should ascertain what specific barriers South African entrepreneurs experience before engaging in any ICT development interventions. One should also be careful about using the phrase 'digital literacy' in the broader sense of the word and to rather focus on the specific industries and build interventions around each specific industry.

\section{Acknowledgements Competing interests}

The author declares that she has no financial or personal relationships that may have inappropriately influenced her in writing this article.

\section{References}

Adeniran, T.V. \& Johnston, K.A., 2016, 'The impacts of ICT utilisation and dynamic capabilities on the competitive South African SMEs', International Journal of Information Technology and Management 15(1), 59-89. https://doi.org/10.1504/ IJITM.2016.073915

Al Mursalin, M.J., 2012, 'Information system adoption and usage: Validating UTAUT model for Bangladeshi SMES', BRAC University Journal 9(1 \& 2), 15-24.

Alam, S.S. \& Noor, M.K.M., 2009, 'ICT adoption in small and medium enterprises: An empirical evidence of service sectors in Malaysia', International Journal of Business and Management 4(2), 112-125. https://doi.org/10.5539/ijbm.v4n2p112

AlAwadhi, S. \& Morris, A., 2008, 'The use of the UTAUT model in the adoption of e-government services in Kuwait', in, 41st Hawaii International Conference on System Sciences, Waikoloa, Big Island, HI, January 7-10 2008, pp. 1-11.

Anderson, J.E. \& Schwager, P.H., 2004, 'SME adoption of wireless LAN technology: Applying the UTAUT model', in 7th Annual Conference of the Southern Association for Information Systems (SAIS), February 27-28 2004, pp. 39-43.

Antonites, A.J. \& Van Vuuren, J.J., 2005, 'Inducing entrepreneurial creativity, innovation and opportunity-finding skills', South African Journal of Economic and Management Science 8(3), 255-271. https://doi.org/10.4102/sajems.v8i3.1197

Bagozzi, R.P., 2007, 'The legacy of the technology acceptance model and a proposal for a paradigm shift', Journal of the Association for Information Systems 8(4), 244-254. https://doi.org/10.17705/1jais.00122

Baker, R.K. \& White, K.M., 2010, 'Predicting adolescents' use of social networking sites from an extended theory of planned behaviour perspective', Computers in Human Behavior 26, 1591-1597. https://doi.org/10.1016/j.chb.2010.06.006

Beck, T. \& Demirgüç-Kunt, A., 2006, 'Mall and medium-size enterprises: Access to finance as a growth constraint', Journal of Banking and Finance 30(11), 2931-2943.

Bhattacherjee, A. \& Sanford, C., 2006, 'Influence processes for information technology acceptance: An elaboration likelihood model', MIS Quarterly 30(4), 805-825. https://doi.org/10.2307/25148755

Botha, M., Nieman, G. \& Van Vuuren, J.J., 2007, 'Measuring the effectiveness of the women entrepreneurship programme on potential, start-up and established women entrepreneurs in South Africa', South African Journal of Economic and Management Science 10(2), 163-183.

Burnkrant, R.E. \& Page, T.J., 1988, 'The structure and antecedents of the normative and attitudinal components of Fishbein's theory of reasoned action', Journa of Experimental Social Psychology 24, 66-87. https://doi.org/10.1016/0022 1031(88)90044-3

Cáceres, R.B., Agüero, A., Cavero, M. \& Huaroto, C., 2012a, 'The impacts of the use of mobile telephone technology on the productivity of micro and small enterprises: An exploratory study into the carpentry and cabinet-making sector in Villa $\mathrm{E}$ Salvador', Information Technologies and International Development 8(4), 77-94.

Cant, M.C., Wiid, J.A. \& Hung, Y., 2016, 'Internet-based ICT usage by South African SMEs: The barriers faced by SMEs', The Journal of Applied Business Research 32(6), 1877-1888. https://doi.org/10.19030/jabr.v32i6.9889

Chatzoglou, P.D. \& Vraimaki, E., 2010, 'Computer acceptance in Greek SMEs', Journa of Small Business and Enterprise Development 17(1), 78-101. https://doi.org/ of Small Business and Enterp
$10.1108 / 14626001011019143$

Cohen, J.F., Bancilhon, J. \& Jones, M., 2013, 'South African physicians' acceptance of e-prescribing technology: An empirical test of a modified UTAUT model', South African Computer Journal 50, 43-53. https://doi.org/10.18489/sacj.v50i1.175

Donner, J. \& Escobari, M.X., 2010, 'A review of evidence on mobile use by micro and small enterprises in developing countries', Journal of International Development 22, 641-658. https://doi.org/10.1002/jid.1717

Duncombe, R. \& Molla, A., 2009, 'Formalisation of information systems in sub-Saharan African small and medium enterprises: Case of Botswana', The African Journal of Information Systems 1(2), 1-29.

Escobar-Rodríguez, T. \& Carvajal-Trujillo, E., 2014, 'Online purchasing tickets for low cost carriers: An application of the unified theory of acceptance and use of technology (UTAUT) model', Tourism Management 43, 70-88. https://doi org/10.1016/j.tourman.2014.01.017

Esselaar, S., Stork, C., Ndiwalana, A. \& Deen-Swarray, M., 2006, 'ICT usage and its impact on profitability of SMEs in 13 African countries', Information and Communication Technologies and Development 4(1), 87-100. https://doi.org/ 10.1162/itid.2007.4.1.87

Fadel, K.J., Durcikova, A. \& Cha, H.S., 2008, 'Elaboration likelihood in knowledge management: A model and experimental test', in 41st Hawaii Internationa Conference on System Sciences, Waikoloa, Big Island, HI, January 7-10 2008, Conference 10.

Gatautis, R. \& Vitkauskaite, E., 2009, 'eBusiness policy support framework', Inzinerine Ekonomika - Engineering Economics 5, 35-47.

Godin, J. \& Goette, T., 2013, 'A review of models: Virtual teamwork training model and UTAUT', in 14th Annual Conference of the Southern Association for Information Systems (SAIS), Savannah, GA, March 8-9 2013, pp. 41-46.

Gono, S., Harindranath, G. \& Berna Ozcan, G., 2016, 'The adoption and impact of ICT in South African SMEs', Strategic Change 25, 717-734. https://doi.org/10.1002/ jsc.2103

Hameed, M.A., Counsell, S. \& Swift, S., 2012, 'A conceptual model for the process of IT innovation adoption in organizations', Journal of Engineering and Technology Management 29, 358-390. https://doi.org/10.1016/j.jengtecman.2012.03.007

Handy, J., Whiddett, R. \& Hunter, I., 2001, 'A technology acceptance model for interorganisational electronic medical records', Australian Journal of Information Systems 9(1), 39-50. https://doi.org/10.3127/ajis.v9i1.226 
Hansen, T., Jensen, J.M. \& Solgaard, H.S., 2004, 'Predicting online grocery buying intention: A comparison of the theory of reasoned action and the theory of intention: A comparison of the theory of reasoned action and the theory of
planned behavior', International Journal of Information Management 24, 539-550. https://doi.org/10.1016/j.ijinfomgt.2004.08.004

Hisrich, R.D. \& Peters, M.P., 1998, Entrepreneurship, 4th edn., Irwin McGraw-Hill, Boston, MA.

Hynes, B., 1996, 'Entrepreneurship education and training - Introducing entrepreneurship into non-business disciplines', Journal of European Industria Training 20(8), 10-17. https://doi.org/10.1108/03090599610128836

Im, I., Hong, S. \& Kang, M.S., 2011, 'An international comparison of technology adoption testing the UTAUT model', Information and Management 48, 1-8. https://doi. org/10.1016/j.im.2010.09.001

Jackson, M. \& Sloane, A., 2009, 'Organisation profiling and the adoption of ICT: E-commerce in the UK construction industry', The Electronic Journal Information Systems Evaluation 12(1), 67-74.

Kabanda, S., 2011, 'E-commerce institutionalization is not for us: SMEs perception of e-commerce in Tanzania', The African Journal of Information Systems 3(1), 1-16.

Kahn, G.F., Moon, J., Rhee, C. \& Rho, J.J., 2012, 'E-government skills identification and development: Toward a staged-based user-centric approach for developing countries', Asia Pacific Journal of Information Systems 20(1), 1-31.

Kapurubandara, M. \& Lawson, R., 2007, 'SMEs in developing countries need support to address the challenges of adopting e-commerce technologies', in 20th Bled $e$-Conference - e-Mergence: Merging and Emerging Technologies, Processes and e-Conference-e-Mergence: Merging and Emerging
Institutions, Slovenia, June 4-6 2007, pp. 485-498.

Kourilsky, M.L., 1995, Entrepreneurship education: Opportunity in search of curriculum, Centre of Entrepreneurial Leadership, Ewing Marion Kaufmann Foundation, Kansas City, MO, pp. 2-25.

Kumar, S., 2013, 'The moderating factors of $3 \mathrm{G}$ user acceptance technology in Shimla (India) using UTAUT model', International Journal of Computer Science and Engineering Technology 4(6), 670-674.

Kunene, T.R., 2008, 'A critical analysis of entrepreneurial and business skills in SMEs in the textile and clothing industry in Johannesburg, South Africa', PhD dissertation, University or Pretoria, Pretoria, South Africa.

Ladzani, W.M. \& Van Vuuren, J.J., 2002, 'Entrepreneurship training for emerging SMEs in South Africa', Journal of Small Business Management 40(2), 154-161.

Lu, J., Yu, C., Liu, C. \& Yao, J.E., 2003, 'Technology acceptance model for wireless internet', Internet Research: Electronic Networking Applications and Policy 13(3), 206-222. https://doi.org/10.1108/10662240310478222

Malebana, J., 2014, 'Entrepreneurial intentions of South African rural university students: A test of the theory of planned behaviour', Journal of Economics and Behavioral Studies 6(2), 130-143.

Marchewka, J.T., Liu, C. \& Kostiwa, K., 2007, 'An application of the UTAUT model for understanding student perceptions using course management software', Communications of the IIMA 7(2), 93-104.

Mavimbela, R. \& Dube, E., 2016, 'Can an internet adoption framework be developed for SMEs in South Africa', Journal of Entrepreneurship and Innovation in Emerging Economies 2(2), 120-135. https://doi.org/10.1177/2393957516647250

Mehrtens, J., Cragg, P.B. \& Mills, A.M., 2001, 'A model of internet adoption by SMEs', Information and Management 39, 165-176.

Merkofer, P. \& Murphy, A., 2009, 'The e-skills landscape in South Africa: The issues of demand and supply and the use of international benchmarks to inform the South African e-skills development context', Zeitschrift für Politikberat 2, 685-695. https://doi.org/10.1007/s12392-010-0219-y

Miller, D. \& Garnsey, E., 2000, 'Entrepreneurs and technology diffusion: How diffusion research can benefit from a greater understanding of entrepreneurship', Technology in Society 22, 445-465.

Mutula, S.M. \& Van Brakel, P., 2007, 'ICT skills readiness for the emerging global digital economy among small business in developing countries: Case study of Botswana' Library Hi Technology 25(2), 231-245. https://doi.org/10.1108/07378830710754992

Ndubisi, N.O. \& Kahraman, C., 2005, 'Malaysian women entrepreneurs: Understanding the ICT usage behaviors and drivers', Journal of Enterprise Information Management 18(6), 721-738. https://doi.org/10.1108/17410390510628418

Nguyen, T.H., 2009, 'Information technology adoption in SMEs: An integrated framework', International Journal of Entrepreneurial Behaviour and Research 15(2), 162-186. https://doi.org/10.1108/13552550910944566

Noll, C.L., 1993, 'Planning curriculum for entrepreneurship education', Business Education Forum 47(3), 1.

Oke, A., Burke, G. \& Myers, A., 2007, 'Innovation types and performance in growing UK' SMEs', International Journal of Operations and Production Management 27(7) 735-753. https://doi.org/10.1108/01443570710756974
Onstenk, J., 2003, 'Entrepreneurship and vocational education', European Educational Research Journal 2(1), 74-89. https://doi.org/10.2304/eerj.2003.2.1.12

Oye, N.D., Ihhad, N.A. \& Ab Rahim, N., 2012, 'The history of UTAUT model and its impact on ICT acceptance and usage by academicians', Educational Information Technology 1(1), 1-20.

Peris, M., Blinn, N., Nuttgens, M., Lindermann, N. \& Von Kortzfleisch, H., 2013, 'Acceptance of professional Web 2.0 platforms in regional SME networks: An evaluation based on the unified theory of acceptance and use of technology', in 46 th Hawaii International Conference on System Sciences, Grand Wailea, Maui, $\mathrm{HI}$, January 7-10 2013, pp. 2793-2802.

Ramalho, V., Moura, A.P. \& Cunha, L.M., 2015, 'Why do small business butcher shops fail to fully implement HACCP?', Food Control 49, 85-91. https://doi.org/10.1016/j. foodcont.2013.11.050

Ramani, S.V., SadreGhazi, S. \& Duysters, G., 2012, 'On the diffusion of toilets as bottom of the pyramid innovation: Lessons from sanitation entrepreneurs', Technological Forecasting and Social Change 79, 676-687. https://doi.org/10.1016/j.techfore. 2011.06.007

Ramdani, B. \& Kawalek, P., 2009, 'Predicting SMEs' adoption of enterprise systems', Journal of Enterprise Information Management 22(1/2), 10-24. https://doi. org/10.1108/17410390910922796

Reimenschneider, C.K., Harrison, D.A. \& Mykytyn, P.P., 2003, 'Understanding IT adoption in small business: Integrating current theories', Information and Management 40, 269-285. https://doi.org/10.1016/S0378-7206(02)00010-1

Republic of South Africa, 1996, National Small Business Act, Act No. 102 of 1996, Government Gazette Pretoria, Government Printing Works.

Spencer, A.J., Buhalis, D. \& Moital, M., 2012, 'A hierarchical model of technology adoption for small owner-managed travel firms: An organizational decisionmaking and leadership perspective', Tourism Management 33, 1195-1208. https://doi.org/10.1016/j.tourman.2011.11.011

Steyn, A.A. \& Leonard, A.C., 2012, 'Guidance for SMEs with the adoption of technology: A conceptual framework', The South African Journal of Entrepreneurship and Small Business Management 5, 24-33. https://doi.org/10.1016/j.tourman. 2011.11.011

Suri, T., 2011, 'Selection and comparative advantage in technology adoption', Econometrica 79(1), 159-209. https://doi.org/10.3982/ECTA7749

Talukder, M., Quazi, A. \& Djatikusumo, D., 2013, 'Impact of social influence on individuals' adoption of social networks in SMEs', Journal of Computer Science 9(12), 1686-1694. https://doi.org/10.3844/jcssp.2013.1686.1694

Teece, D.J., 2007, 'Explicating dynamic capabilities: The nature and microfoundations of (sustainable) enterprise performance', Strategic Management Journal 28 , 1319-1350. https://doi.org/10.1002/smj.640

Teece, D.J., Pisano, G. \& Shuen, A., 1997, 'Dynamic capabilities and strategic management', Strategic Management Journal 18(7), 509-533. https://doi.org/ management', Strategic Management Journal 18(7), 509-533. http
10.1002/(SICI)1097-0266(199708)18:7<509::AID-SMJ882>3.0.CO;2-Z

Thomas, B., Packham, G., Miller, C. \& Brooksbank, D., 2004, 'The use of web sites for SME innovation and technology support services in Wales', Journal of Small Business and Enterprise Development 11(3), 400-407. https://doi.org/10.1108/ 14626000410551654

Thompson, P., Williams, R., Thomas, B. \& Packham, G., 2010, Shortages of ICT skills in UK SMEs, viewed 10 May 2012, from http://www.isbe.org.uk/content/assets/ G._ICT_ICT_and_E-Business_in_the_Small_Firm_Sector-_Piers_Thompson.pdf

Twinomurinzi, H., Phahlamohlaka, J. \& Byrne, E., 2012, 'The small group subtlety of using ICT for participatory governance: A South African experience', Government Information Quarterly 29, 203-211. https://doi.org/10.1016/j.giq.2011.09.010

Uddin, M.K., 2005, 'The role of diffusion of innovations for incremental development in small enterprises', Technovation 26, 274-284. https://doi.org/10.1016/j. technovation.2005.04.001

Venkatesh, V., Morris, M.G., Davis, G.B. \& Davis, F.D., 2003, 'User acceptance of information technology: Toward a unified view', MIS Quarterly 27(3), 425-478. https://doi.org/10.2307/30036540

Wamuyu, P.K. \& Maharaj, M., 2011, 'Factors influencing successful use in mobile technologies to facilitate e-commerce in small enterprises: The case of Kenya', The African Journal of Information systems 3(2), 47-71.

Wonglimpiyarat, J. \& Yuberk, N., 2005, 'In support of innovation management and Roger's innovation diffusion theory', Government Information Quarterly 22(3) 411-422. https://doi.org/10.1016/j.giq.2005.05.005

Yu, C., 2012, 'Factors affecting individuals to adopt mobile banking: Empirical evidence from the UTAUT model', Journal of Electronic Commerce Research 13(2), 104-121.

Yu, T.F., 2001, 'Towards a capabilities perspective of the small firm', International Journal of Management Reviews 3(3), 185-197. https://doi.org/10.1111/1468 2370.00063 